\title{
Does Consanguinity Protect Against Breast Cancer in Tunisian Population?
}

\author{
Troudi Cherif $\mathbf{W}^{1-3^{*}}$, Uhrhummer $\mathbf{N}^{4}$, Ben Ayed $\mathrm{F}^{2}$, Bignon $\mathbf{Y J}^{3}$, Sibille $\mathbf{C}^{5}$, Benammar-Elgaaied $\mathbf{A}^{1}$ and Ennafaa $\mathbf{H}^{1}$ \\ ${ }^{1}$ Laboratory of Genetics, Immunology and Human Pathology at the Faculty of Sciences of Tunis, Faculty of Sciences of Tunis, University El Manar I 1060 Tunis, Tunisia \\ ${ }^{2}$ Central University 03, Rue Hammadi Eljaziri, 1002 Tunis, Tunisia \\ ${ }^{3}$ Salah Azaiez Institute of Carcinology of Tunis, Boulevard 09 Avril - 1006 Bab Saadoun Tunisia \\ ${ }^{4}$ Laboratoire de Diagnostic Genetique et Moleculaire, Centre Jean-Perrin. 63011 Clermont-Ferrand, Cedex 01 France \\ ${ }^{5}$ Laboratory of Molecular Genetic of Hereditary Pathologies, Center of Human Genetics UCL, Avenue E.Mounier- Entree F. B 1200 Bruxelles \\ *Corresponding author: Wafa Troudi Cherif, Central University 03, Rue Hammadi Eljaziri, 1002 Tunis. Tunisia, Tel: 0021671793379 (144)/ Fax: 0021671793558; E- \\ mail: Wafa_t@yahoo.com
}

Rec date: Nov 20, 2013, Acc date: May 13, 2014, Pub date: May 15, 2014

Copyright: (C) 2014 Cherif WT, et al. This is an open-access article distributed under the terms of the Creative Commons Attribution License, which permits unrestricted use, distribution, and reproduction in any medium, provided the original author and source are credited.

\begin{abstract}
Consanguinity is highly prevalent in many parts of the world. The highest consanguinity rates $(20 \%$ to $50 \%$ of all marriages) occur in North Africa, the Middle East, Southwest Asia and Southern India. The aim of this study is to assess the effect of consanguineous marriages on the incidence of sporadic and familial breast cancer in Tunisia.

We ascertained the rate of consanguineous marriage and the average coefficient of inbreeding among 155 Tunisian patients diagnosed with sporadic or familial breast cancer.

The coefficient of inbreeding among all breast cancer patients was 0,007. No difference was observed for sporadic $(F=0.008)$ vs familial breast cancer $(F=0.007)$. The coefficient of inbreeding was significantly lower in the breast cancer group than in the Tunisian general population $(0.0157)$. Considering the age of the patients, the level of inbreeding was lower among patients older than $50(\mathrm{~F}=0.0027)$, while those younger than 50 exhibited a coefficient of inbreeding similar to that of the general population $(F=0.01)$.

The protective effect of consanguinity against breast cancer, particularly for patients older than 50 years, may be related to the absence of major factors involved in the onset of breast cancer at an early age. This protective effect may be also related to the contribution of recessive alleles of modifier or low-penetrance genes in the homozygous state.
\end{abstract}

Keywords: Consanguinity; Breast cancer; Coefficient of inbreeding; Tunisian population

\section{Introduction}

Consanguinity is highly prevalent in many parts of the world. The highest consanguinity rates ( $20 \%$ to $50 \%$ of all marriages) are observed in North Africa, the Middle East, Southwest Asia and Southern India $[1,2]$. The average inbreeding coefficient reaches 0.02265 in the Saudi population; 0.02442 in Yemen and 0.0157 in Tunisia [3]. In contrast to these Eastern regions, the mean coefficient of inbreeding was estimated at 0.0002 in the United Kingdom [4]. Western European and Northern American countries display low consanguineous marriage rates (less than 1\%) [5].

Consanguinity may affect the frequency of the genetically determined diseases. In multifactorial diseases such as cancer, the effect of consanguinity is less obvious. Studies from Pakistan, Croatia and North America suggest that parental consanguinity increases the risk of breast cancer in women, particularly younger women and those from first-cousin marriages [6,7]. However, studies from the Arabian Peninsula reported that consanguinity may lessen the overall risk of breast cancer, especially in younger women $[8,9]$. These contradictory findings create uncertainty about the real risk of breast cancer among women with consanguineous parentage.
Involvement of genetic factors and role of consanguinity in the development of breast cancer may be different in familial versus sporadic cases. We assessed possible effect of parental consanguinity in patients with sporadic breast cancer and others with familial breast cancer by comparing their level of inbreeding with that in general population.

\section{Material and Methods}

\section{Study subjects}

Patients were recruited prospectively from the main cancer hospital (ISA: Salah Azaiez Institute of Carcinology) in Northern Tunisia. The recruitment lasted one year. All patients were locally born in Tunisia, with histological diagnosis of breast cancer. On the basis of family history of the disease, patients were classified into familial and sporadic groups. A total of 78 sporadic and 77 familial breast cancer cases were included.

Familial breast cancer was defined by the presence of more than two cases of breast cancer in the family. Among these families, hereditary breast cancer might be defined according to clear BRCA1 or BRCA2 suggestivity. BRCA1 mutation suggestivity is defined as the index case of family with at least three female relatives affected with breast and/or ovarian cancer and the absence of male breast cancer. 
Page 2 of 4

The presence of a male proband or a male relative diagnosed with breast cancer is suggestive of BRCA2 mutation [10].

The 77 cases with familial breast cancer were classified into groups according to the selection criteria adopted by Troudi et al (2007) [10]. Group 1 includes patients with history of breast and ovarian cancer, Group 2 includes patients with history of breast cancer only and Group 3 includes patients with male breast cancer in the family. Group 4 includes patients with familial breast cancer with no evidence of involvement of major genes.

\section{Data Collection}

The ethics committee of the ISA approved the study, and all patients consented to this investigation. Tumour characteristics were ascertained from pathology reports. Parameters such as grade and stage, as well as age at diagnosis were taken into account in comparing between the two groups and to a larger group of "historical controls".

\section{Familial and consanguinity analysis}

Pedigrees were established for each patient for at least three generations. Three factors were taken into account: age at diagnosis of the proband, the familial link between the proband's parents, breast or ovarian cancer cases in the family. The coefficient of inbreeding was calculated for each patient and the mean coefficient of inbreeding $(\mathrm{F})$ was determined for each group in standard manner [11].

Data were analyzed using a statistical test (Epi 6 Info package) to compare the mean values between two groups. p values less than 0.05 were considered statistically significant.

\section{Results}

One hundred fifty five (155) patients from 23 to 73 years of age (median age 48 years) were diagnosed for breast cancer. Among these cases, 78 had sporadic and 77 had familial type of disease. Clinical and pathological characteristics of sporadic breast cancer cases were comparable to those previously reported in the same population (Table 1).

\begin{tabular}{|l|l|l|l|}
\hline Variable & $\begin{array}{l}\text { Sporadic } \\
\text { cases }\end{array}$ & $\begin{array}{l}\text { Historical controls Patients } \\
\text { diagnosed in 2004 [12] }\end{array}$ & $p$ \\
\hline Age at onset & 47 & 51 & \\
\hline Pathology stage & & & 0.36 \\
\hline $\begin{array}{l}\text { Early (0, I, II) } \\
\text { Late (III, IV) }\end{array}$ & $53.5 \%$ & $59.0 \%$ & 0.80 \\
\hline Histopathology & $46.4 \%$ & $45.9 \%$ & 0.14 \\
\hline $\begin{array}{l}\text { Infiltrating ductal } \\
\text { carcinoma }\end{array}$ & $91.3 \%$ & $86.6 \%$ & 0.01 \\
\hline Tumor grade & & $54.5 \%$ & \\
\hline I and II & $40.0 \%$ & & \\
\hline
\end{tabular}

Table 1: Clinical and histopathological characteristics of patients with sporadic breast cancer compared to those diagnosed in 2004
Inbreeding characteristics of patients with breast cancer are shown in table 2 .

\begin{tabular}{|l|l|}
\hline Mean age & $46.3(23-73)$ \\
\hline Parents consanguineous No & $136(87.7 \%)$ \\
\hline Yes & $19(12.25 \%)$ \\
\hline First cousin $(F=1 / 16)$ & $16(84.2 \%)$ \\
\hline Second cousin $(F=1 / 64)$ & $1(5.25 \%)$ \\
\hline Double first cousin $(F=1 / 8)$ & $1(5.25 \%)$ \\
\hline$F=1 / 13$ & $1(5.25 \%)$ \\
\hline
\end{tabular}

Table 2: Inbreeding characteristics of breast cancer patients $(n=155)$

In general Tunisian population, the mean coefficient of inbreeding previously reported was 0.0157 . The mean coefficient of inbreeding among breast cancer patients was 0.007. This coefficient was not significantly different between patients group with sporadic cancer and those with familial malignancy (Table 3 ).

\begin{tabular}{|l|l|l|}
\hline \multicolumn{2}{|l|}{ Number of cases } & $\begin{array}{l}\text { Mean coefficient of inbreeding } \\
(\mathbf{F})\end{array}$ \\
\hline $\begin{array}{l}\text { Sporadic breast } \\
\text { cancer }\end{array}$ & 78 & 0.008 \\
\hline Familial breast cancer & 77 & 0.007 \\
\hline Total cases & 155 & 0.007 \\
\hline
\end{tabular}

Table 3: Coefficient of inbreeding in sporadic and familial breast cancer patient groups

Prevalence of consanguineous marriage was $12.25 \%$ for breast cancer probands, which is lower than the $30 \%$ found in the general population [3]. Eighty-nine cases (65\%) were less than 50 years old, among which $15.7 \%$ were consanguineous. Only $4.25 \%$ of cases aged more than 50 years were consanguineous (Table 4 ).

Level of inbreeding was lower among patients older than 50 $(\mathrm{F}=0.0027)$, while those younger than 50 , coefficient of inbreeding was similar to that of the general population $(\mathrm{F}=0.01)$ (Table 4).

Presence of BRCA1/2 mutations and parental consanguinity in patients with familial breast cancer was shown in table 5. Five out of 12 patients analysed in Group 1 and one of 22 in Group 2 carried deleterious mutations in BRCA1 or BRCA2 (Table 5). Familial and molecular analysis distinguished between Groups 1 and 3 in which frequently involve BRCA mutations, and Groups 2 and 4 with less obvious genetic determinism.

Consanguineous cases are less frequent in Groups 1 and 3 than in Groups 2 and 4, with one consanguineous marriage observed among 17 cases $(5.8 \%)$ in the first two groups and $7 / 60(11.6 \%)$ in the two others (Group 2 and 4). The rate of consanguineous marriage was increased in group 4. 


\begin{tabular}{|c|c|c|c|c|c|c|}
\hline & $\begin{array}{l}\text { Mean coefficient of } \\
\text { inbreeding (F) }\end{array}$ & $\begin{array}{l}\text { Age of } \\
\text { onset }\end{array}$ & $\begin{array}{l}\text { Number of patients per } \\
\text { group }\end{array}$ & $\begin{array}{l}\text { Number of } \\
\text { consanguineous } \\
\text { marriages per group }\end{array}$ & $\begin{array}{l}\text { Coefficient of inbreeding per } \\
\text { group } F\end{array}$ & $P$ value \\
\hline \multirow{2}{*}{$\begin{array}{l}\text { Total cases } \\
\text { (136) }\end{array}$} & \multirow[t]{2}{*}{0.007} & \multirow{2}{*}{$\begin{array}{l}<50 \\
>50\end{array}$} & 89 & 14 & 0.01 & 0.04 \\
\hline & & & 47 & 2 & $\begin{array}{l}0 \\
0 \\
0 \\
2 \\
7\end{array}$ & \\
\hline
\end{tabular}

Table 4: The protective effect of consanguinity among patients with breast cancer

\begin{tabular}{|l|l|l|l|l|l|l|}
\hline Group & Total cases & Age $\mathbf{5 0}$ & Age $\mathbf{5 0}$ & $\begin{array}{l}\text { Consanguineous } \\
\text { cases }\end{array}$ & Sequenced cases & BRCA1/2 Mutation \\
\hline 1 & 13 & 8 & 5 & 0 & 12 & 5 \\
\hline 2 & 45 & 34 & 11 & 3 & 1 & 22 \\
\hline 3 & 4 & 2 & 2 & 4 & 2 & 1 \\
\hline 4 & 15 & 11 & 4 & 0 & 1 & ND \\
\hline
\end{tabular}

Table 5: Consanguineous marriages in familial breast cancer patients (ND: Non Determined)

\section{Discussion}

We studied 155 breast cancer cases treated at the Salah Azaïez Institute (ISA) of Tunis, the main oncology Center in Northern Tunisia. 1437 breast cancer cases are treated at the ISA annually [12], of which familial cases represent about $5 \%$ ( 72 cases per year). The 77 familial cases analyzed in this study may correspond to the number of familial cases diagnosed per year, suggesting that sample is representative of familial breast cancer cases in Northern Tunisia.

The number of patients with sporadic breast cancer (78) corresponds to $5 \%$ of breast cancer cases in ISA. Their clinical and pathological parameters were similar to those previously published in this population; therefore, this group is representative of sporadic breast cancer in Tunisian population.

Patients with breast cancer have lower rates of both consanguineous marriages and mean coefficient of inbreeding than general population of Tunis. This result is similar to that of Denic, who demonstrated that in some areas, parental consanguinity was more frequent among healthy women than those with breast cancer [8].

Patients older than 50 years had a coefficient of inbreeding lower than that of patients younger than 50 , independently of the sporadic or familial presentation of the disease $(\mathrm{p}=0.04)$. For patients younger than 50 , the average coefficient of inbreeding was similar to that of the general population, suggesting that consanguinity would be protective against breast cancer after 50 years. In contrast, Middle Eastern women whose parents are consanguineous have been shown to have a lower risk of developing breast cancer before age 50 than women of non-consanguineous parents, and this effect was not found with those older than 50 [8].

BRCA1/2 mutations are likely lethal in homozygotes. Earlier study suggested that long history and high rate of consanguineous marriages would decrease the frequency of BRCA1/2 mutations; this may explain a low rate of BRCA1/2 in some consanguineous populations [13]. In our study, absence of parental consanguinity in all seven patients with BRCA1/2 mutations supports this hypothesis.

Some recessive low-penetrance alleles are protective against cancer [14]. As homozygotes of such alleles would be less likely to develop breast cancer, higher rate of inbreeding could be protective against this malignancy. This is possible explanation for our findings of a lower rate of inbreeding amongst breast cancer patients.

In conclusion, parental consanguinity seems to protect against breast cancer especially those older than 50 years. Further confirmation of these findings and study of mechanism by which inbreeding lowers odds of malignancy deserve additional study.

\section{Acknowledgements}

This work was funded in part by the Laboratory of Molecular Genetics, Immunology and Human Pathologies at the Faculty of Science of University Tunis El manar, the Institute of Carcinology Salah Azaiez. It was supported by IncoMed project Number: ICACT-2002-10005.

\section{References:}

1. Alwan A, Modell (1997) Hereditary disorders in the Eastern Mediterranean Region: role of customary consanguineous marriage. In: Community Control of Genetic and Congenital Disorders. EMRO Technical publication Series 24. Alexandria, Egypt, WHO.

2. Khlat M (1997) Endogamy in the Arab World. In: Genetic Disorders among Arab Populations. Teebi AS and Farag TI (eds). Oxford University Press, New York.

3. Chalbi N, Zakaria D (1998) ModÃ "les de famille, endogamie et consanguinitÃ@ apparente en Tunisie. Essais de mesure. Famille et population 1:39-59.

4. Smith MT (2001) Estimates of cousin marriage and mean inbreeding in the United Kingdom from 'birth briefs'. J Biosoc Sci 33: 55-66. 
Citation: Cherif WT, Uhrhummer N, Ayed FB, Bignon YJ, Sibille C, et al. (2014) Does Consanguinity Protect Against Breast Cancer in Tunisian Population?. Hereditary Genet 3: 130. doi:10.4172/2161-1041.1000130

Page 4 of 4

5. Liascovich R, Rittler M, Castilla EE (2001) Consanguinity in South America: demographic aspects. Hum Hered 51: 27-34.

6. Shami SA, Qaisar R, Bittles AH (1991) Consanguinity and adult morbidity in Pakistan. Lancet 338: 954.

7. Simpson JL, Martin AO, Elias S, Sarto GE, Dunn JK (1981) Cancers of the breast and female genital system: search for recessive genetic factors through analysis of human isolate. Am J Obstet Gynecol 141: 629-636.

8. Denic S, Bener A (2001) Consanguinity decreases risk of breast cancercervical cancer unaffected. Br J Cancer 85: 1675-1679.

9. Denic S, Frampton C, Nicholls MG (2007) Risk of cancer in an inbred population. Cancer Detect Prev 31: 263-269.

10. Troudi W, Uhrhammer N, Sibille C, Dahan C, Mahfoudh W, et al. (2007) Contribution of the BRCA1 and BRCA2 mutations to breast cancer in Tunisia. J Hum Genet 52: 915-920.
11. Sofaer JA (1990) Population genetics (Hardy-Weinberg equilibrium and factors affecting it). In Principles and Practice of Medical Genetics. Emery AEH and Rimoin DL (eds). Churchill Livingston, New York 121-132.

12. Maalej M, Hentati D, Messai T, Kochbati L, El May A, et al. (2008) Breast cancer in Tunisia in 2004: a comparative clinical and epidemiological study. Bull Cancer 95: E5-9.

13. Denic S, Al-Gazali L (2003) BRCA1 and BRCA2 mutations in breast cancer patients from Saudi Arabia. Saudi Med J 24: 696.

14. Denic S, Al-Gazali L (2002) Breast cancer, consanguinity, and lethal tumor genes: simulation of BRCA1/2 prevalence over 40 generations. Int J Mol Med 10: 713-719. 